\title{
Determinan Minat Wajib Pajak dalam Menerapkan Sistem E-Filling di KPP Pratama Badung Selatan
}

\author{
Ni Luh Putu Sukma Pradnyani ${ }^{1}$ \\ Fakultas Ekonomi dan Bisnis \\ Universitas Udayana, Indonesia
}

\author{
I Ketut Jati ${ }^{2}$ \\ Fakultas Ekonomi dan Bisnis \\ Universitas Udayana, Indonesia
}

\section{Surel : sukmapradnyani111@gmail.com}

ABSTRAK

Penelitian ini bertujuan untuk mendapatkan bukti empiris pengaruh kesiapan teknologi informasi, persepsi kebermanfaatan, efektivitas sistem, dan kelayakan sistem pada minat wajib pajak dalam menerapkan sistem e-filling. Technology Acceptance Model (TAM) dan Task Technology Fit (TTF) digunakan sebagai landasan teori untuk menjelaskan pengaruh kesiapan teknologi informasi, persepsi kebermanfaatan, efektivitas sistem, dan kelayakan sistem pada minat wajib pajak dalam menerapkan sistem e-filling. Jumlah sampel yang digunakan dalam penelitian sebanyak 100 responden dengan metode penentuan sampel purposive sampling. Teknik analisis yang digunakan adalah analisis regresi linier berganda. Hasil analisis mengindikasikan bahwa kesiapan teknologi informasi dan kelayakan sistem meningkatkan minat wajib pajak dalam menerapkan sistem e-filling, sedangkan persepsi kebermanfaatan dan efektivitas sistem tidak berpengaruh pada minat wajib pajak dalam menerapkan sistem e-filling.

\section{Kata Kunci: Kesiapan Teknologi Informasi; Persepsi Kebermanfaatan; Efektivitas Sistem; Kelayakan Sistem; Minat Menerapkan Sistem E-Filling.}

\section{Determinants of Taxpayers' Interest in Using the E-Filling System at KPP Pratama South Badung}

\begin{abstract}
This study aims to obtain empirical evidence of the effect of information technology readiness, perceived usefulness, system effectiveness, and system feasibility on taxpayers' interest in implementing the e-filling system. The Technology Acceptance Model (TAM) and Task Technology Fit (TTF) are used as a theoretical basis to explain the effect of information technology readiness, perceived usefulness, system effectiveness, and system feasibility on taxpayers' interest in implementing the e-filling system. The number of samples used in the study were 100 respondents with purposive sampling method of determining the sample. The analysis technique used is multiple linear regression analysis. The results of the analysis indicate that information technology readiness and system feasibility have a positive and significant effect on taxpayers' interest in implementing the e-filling system, while perceptions of the usefulness and effectiveness of the system have no effect on the interest of taxpayers in implementing the e-filling system.
\end{abstract}

Keywords: Information Technology Readiness; Perceptions of Usefulness; System Effectiveness; System Eligibility; Interest in Implementing the E-Filling System.

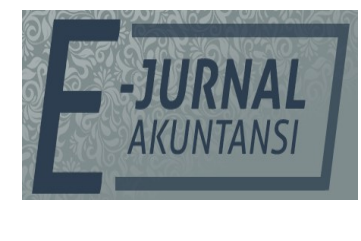

e-ISSN 2302-8556

Vol. 31 No. 7

Denpasar, Juli 2021

Hal. 1838-1853

DOI:

10.24843/EJA.2021.v31.i07.p18

PENGUTIPAN:

Pradnyani, N.L.P.S., \& Jati, I

K. (2021). Determinan Minat

Wajib Pajak dalam

Menerapkan Sistem E-Filling di KPP Pratama Badung

Selatan. E-Jurnal Akuntansi,

31(7), 1838-1853

RIWAYAT ARTIKEL: Artikel Masuk: 2 April 2021 Artikel Diterima:

7 Juni 2021

Artikel dapat diakses : https://ojs.unud.ac.id/index.php/Akuntansi/index 


\section{PENDAHULUAN}

Pajak merupakan salah satu sumber pendapatan negara yang dipungut berdasarkan ketentuan Undang-Undang serta aturan pelaksanaannya. Sektor pajak adalah salah satu sektor di mana hampir semua sumber pendapatan negara diperoleh (Paramaduhita \& Mustikasari, 2018). Oleh karena itu, pajak memegang peran penting dalam pembangunan, karena anggaran utama pembangunan berasal dari pajak (Adnyana \& Yuesti, 2020) .

Berdasarkan data Badan Pusat Statistik tahun 2020, jumlah penerimaan negara yang berasal dari pajak sebesar 1.865.702,80 miliar rupiah, sedangkan penerimaan yang bukan berasal dari pajak sebesar 366,995,10 miliar rupiah. Hal ini menunjukkan bahwa sekitar 83,5 persen sumber penghasilan negara berasal dari sektor perpajakan. Oleh karena itu pemungutan pajak di Indonesia menjadi perhatian bagi suatu pemerintahan. Instansi pemerintahan yang diberi wewenang sebagai pengumpul penerimaan pajak di negara Indonesia adalah Direktorat Jenderal Pajak.

Pada tahun 1984, pemerintah melakukan reformasi perpajakan (tax reform) dengan merubah sistem pemungutan pajak dari official assessment system menjadi self assessment system (Bawazier, 2011). Digantinya sistem pemungutan pajak diharapkan wajib pajak lebih mandiri dan aktif dalam melakukan kewajiban perpajakan.

Perkembangan teknologi yang sangat pesat di era globalisasi saat ini telah memberikan banyak manfaat dalam kemajuan diberbagai aspek kehidupan. Teknologi pada dasarnya dibuat dan dikembangkan oleh manusia untuk mempermudah setiap pekerjaan (Nurhayati et al., 2020). Seiring dengan perkembangan teknologi informasi yang cukup pesat, banyak pemerintahan di seluruh dunia telah mengintegrasikan teknologi informasi dan komunikasi untuk memberikan layanan yang lebih baik dan nyaman dalam program e-governance (Prawati \& Britania, 2020).

Usaha yang dilakukan oleh pemerintah dalam meningkatkan penerimaan pajak, pemerintah melakukan modernisasi perpajakan dalam hal pemanfaatan teknologi informasi dalam sistem pembayaran dan pelaporan pajak (Martini \& Adriati, 2020). Sistem perpajakan online mendapatkan perhatian yang besar secara global melalui perkembangan teknologi informasi yang berdampak pada sistem administrasi perpajakan (Mustapha \& Obid, 2015). Salah satu bentuk digitalisasi sistem pelaporan pajak yang berbasis online yaitu e-filling.

E-filling adalah suatu cara penyampaian SPT secara elektronik yang dilakukan online dan realtime melalui internet pada website Direktorat Jenderal Pajak atau Penyedia Jasa Aplikasi Perpajakan atau Application Service Provider (ASP), dengan adanya sistem ini, para wajib pajak akan lebih mudah melaksanakan kewajiban pajak tanpa harus mengantri di kantor pelayanan pajak sehingga dirasa lebih efektif dan efisien (Damayanti \& Fauzi, 2016).

Meningkat atau menurunnya penggunaan sistem e-filling ini dapat terbentuk dari suatu ketertarikan atau minat dari wajib pajak orang pribadi untuk menggunakan sistem e-filling dalam penyampaian SPT (Nur \& Valentinus, 2020).

Berdasarkan data DJP menunjukkan bahwa penyampaian SPT wajib pajak orang pribadi menggunakan sistem e-filling mengalami penurunan di tahun 2019 
sebesar 829 atau sebesar 3,8 persen, hal ini berbanding terbalik dengan data tahun 2015 sampai 2018 yang dari tahun ke tahun mengalami peningkatan.

Banyak faktor yang mempengaruhi minat wajib pajak orang pribadi dalam menerapkan sistem e-filling. Devina \& Waluyo (2016) meneliti mengenai beberapa faktor yang mempengaruhi penggunaan e-filling yaitu persepsi kegunaan, persepsi kemudahan, kecepatan, keamanan dan kerahasiaan serta kesiapan teknologi informasi. Perkasa (2016) beberapa faktor yang mempengaruhi minat menggunakan e-filling sebagai sarana pelaporan pajak yaitu persepsi kebermanfaatan, persepsi kemudahan penggunaan dan persepsi kepercayaan. Fadlo'lilah (2018) meneliti faktor yang mempengaruhi penggunaan $e$-filling yaitu persepsi kegunaan, persepsi kemudahan, persepsi keamanan dan kerahasiaan, efektivitas sistem, dan kelayakan sistem, dan kepuasan wajib pajak.

Penelitian ini memilih variabel kesiapan teknologi informasi, persepsi kebermanfaatan, efektivitas sistem, dan kelayakan sistem. Variabel kesiapan teknologi informasi dipilih karena dengan adanya perkembangan media internet dan mengingat bahwa media internet merupakan sarana utama dalam menggunakan sistem $e$-filling. Variabel persepsi kebermanfaatan dipilih sebagai faktor yang mempengaruhi minat wajib pajak dalam menerapkan sistem $e$-filling karena suatu sistem dapat dikatakan bermanfaat jika sistem tersebut dapat memenuhi kebutuhan pengguna. Variabel efektivitas sistem dan kelayakan sistem sebagai faktor yang mempengaruhi minat wajib pajak dalam menerapkan sistem e-filling karena suatu sistem dapat dikatakan efektif jika sistem mampu menghasilkan informasi yang dapat diterima dan memenuhi harapan sehingga layak untuk digunakan.

Di seluruh dunia otoritas pajak menganut sistem e-government dan layanan e-tax, sehingga kesiapan teknologi informasi sangat penting. Kesiapan teknologi informasi adalah ukuran yang menunjukkan seberapa siap suatu teknologi dapat diterapkan dan sumber daya yang menjalankan sistem tersebut, dalam hal ini penggunaan sistem e-filling. Hal ini didukung oleh penelitian yang dilakukan Desmayanti (2012) menunjukkan hasil bahwa kesiapan teknologi informasi berpengaruh signifikan positif terhadap intensitas perilaku dalam penggunaan $e$ filling. Hasil penelitian ini juga sejalan dengan penelitian Wibisono \& Toly (2014) dan (Ming Ling \& Muhammad, 2006) menunjukkan hasil bahwa variabel kesiapan teknologi informasi mempengaruhi minat wajib pajak dalam menggunakan $e$ filling. Namun hasil penelitian ini tidak sejalan dengan penelitian Devina \& Waluyo (2016) yang menunjukkan hasil bahwa kesiapan teknologi informasi tidak memiliki pengaruh terhadap penggunaan e-filling. Perbedaan hasil ini yang menjadi dasar peneliti memilih variabel kesiapan teknologi informasi.

Variabel lain yang mempengaruhi minat wajib pajak dalam menerapkan sistem $e$-filling adalah persepsi kebermanfaatan. Persepsi kebermanfaatan adalah tingkatan sejauh mana seseorang yakin bahwa menggunakan sebuah sistem akan meningkatkan kinerjanya. Dalam hal ini, seberapa besar manfaat sistem e-filling untuk wajib pajak pada saat menggunakan sistem $e$-filling pada saat pelaporan SPT (Aliah, 2020). Salah satu manfaat utama yang di rasakan para wajib pajak saat menggunakan sistem e-filling adalah sistem ini di gunakan kapan saja karena sistem beroperasi 24 jam sehari dan tujuh hari seminggu (Tahar et al., 2020). 
Hal ini didukung oleh penelitian Perkasa (2016) menemukan hasil bahwa persepsi kebermanfaatan berpengaruh terhadap penggunaan e-filling. Hasil penelitian ini juga sejalan dengan Noviandini (2012) menemukan hasil bahwa persepsi kebermanfaatan berpengaruh terhadap penggunaan e-filling sebagai sarana pelaporan pajak. Namun hasil peneltian ini tidak sejalan dengan penelitian Sesa (2014) yang menunjukkan bahwa persepsi kebermanfaatan e-filling tidak berpengaruh terhadap kepatuhan dalam menyampaikan SPT Tahunan. Perbedaan hasil ini yang menjadi dasar peneliti memilih variabel persepsi kebermanfaatan.

Selain persepsi kebemanfaatan ada faktor lain yang dapat mempengaruhi minat wajib pajak dalam menerapkan sistem e-filling yaitu efektivitas sistem dan kelayakan sistem. Efektivitas sistem adalah suatu keadaan yang menunjukkan tingkat keberhasilan atau pencapaian suatu sistem yang diukur dengan kualitas, kuantitas, dan waktu sesuai dengan yang telah direncanakan. Kelayakan sistem adalah suatu ukuran yang digunakan untuk menentukan akan seberapa menguntungkan dan praktis sistem tersebut digunakan. Suatu sistem dapat dikatakan efektif jika sistem tersebut dapat memberikan pengaruh yang positif terhadap penggunanya.

Dalam hal ini penggunaan sistem $e$-filling, dengan adanya sistem $e$-filling ini dapat memberikan kemudahan bagi para Wajib Pajak dalam menyampaikan SPTnya. Dengan adanya sistem e-filling ini penyampaian SPT dapat dilakukan kapan saja dan dimana saja sehingga dapat menghemat biaya dan waktu, karena hanya dengan menggunakan komputer yang terhubung dengan internet. Adanya kemudahan yang diberikan sistem $e$-filling, sistem $e$-filling layak di gunakan sebagai sistem pelaporan perpajakan. Hal ini didukung oleh penelitian Sugiharti (2015) menemukan hasil bahwa efektivitas dan kelayakan sistem berpengaruh terhadap penggunaan $e$-filling.

Technology Acceptance Model (TAM) adalah salah satu model yang dapat digunakan ketika bagaiamana sikap pengguna disajikan dengan teknologi baru, faktor-faktor yang mempengaruhi diterimanya suatu sistem informasi, dan niat dari pengguna untuk menggunakan teknologi tersebut (Ariyanto et al., 2014; Davis et al., 1989; Davis \& Venkatesh, 1996; Gefen \& Straub, 2000; Venkatesh \& Davis, 2000). Faktor penting yang mempengaruhi keputusan pengguna bagaimana dan kapan pengguna akan menggunakannya adalah kegunaan yang di rasakan dan kemudahan penggunaan yang di rasakan (Ariyanto et al., 2020; Rakhmawati et al., 2020). Model ini pertama kali diperkenalkan oleh Fred Davis pada tahun 1986. Tujuan dari TAM adalah menjelaskan faktor penentu penerimaan teknologi berbasis informasi dan menjelaskan perilaku pengguna teknologi informasi dengan variasi yang cukup luas populasi penggunanya (Siregar, 2011). Technology Acceptance Model (TAM) dalam penelitian ini digunakan sebagai dasar adanya kesiapan teknologi dan persespsi kebermanfaatan yang dapat mempengaruhi perilaku individu dalam menentukan apakah individu berniat untuk menggunakan teknologi dalam memenuhi kewajiban perpajakannya atau tidak.

Task Technology Fit (TTF) dikembangkan oleh Goodhue \& Thompson (1995). TTF menjelaskan bagaimana teknolgi berdampak dalam membantu individu mengerjakan tugas. Secara langsung teori ini berpegang bahwa teknologi memiliki 
dampak positif terhadap kinerja individu dan dapat digunakan jika kemampuan teknologi tersebut cocok dengan tugas-tugas yang harus dihasilkan oleh pengguna (Tam \& Oliveira, 2016).

Goodhue \& Thompson (1995) mengembangkan ukuran TTF yang terdiri dari 8 faktor yaitu, kemudahan penggunaaan/pelatihan, kualitas, locatability, otorisasi, kompatibilitas, ketepatan waktu, kehandalan sistem, dan hubungan dengan pengguna. Task Technology Fit (TTF) di dalam penelitian ini digunakan sebagai atas dasar hipotesis ketiga, dan keempat yaitu efektivitas sistem dan kelayakan sistem merupakan suatu manfaat yang diberikan e-filling sehingga hal tersebut berpengaruh terhadap minat wajib pajak dalam penggunaan $e$-filling. Berdasarkan penjelasan, TTF merupakan suatu model untuk meningkatkan hasil kinerja ketika sebuah teknologi menyediakan fitur dan dukungan yang tepat yang dikaitkan dengan fungsi penggunaannya.

Minat dapat didefinisikan sebagai rasa ketertarikan seseorang akan suatu objek atau aktivitas yang murni dalam dirinya sendiri (Islam, 2011; Lim \& Ting, 2012). Pada dasarnya minat adalah bentuk penerimaan atas keinginan diri sendiri dengan suatu objek atau aktifitas, yang dalam penelitian ini objek atau aktivitasnya adalah penggunaan e-filing. Minat penggunaan e-filing didasari oleh persepsi wajib pajak terhadap e-filing, serta pengalaman yang didapat oleh wajib pajak dari e-filing. Dapat dikatakan, minat penggunaan e-filing adalah ukuran kekuatan dari minat seseorang untuk menggunakan atau tidak menggunakan terhadap adanya sistem $e$-filing.

Kesiapan teknologi informasi wajib pajak berarti bahwa individu dalam hal ini siap menerima perkembangan teknologi yang termasuk dengan munculnya sistem e-filling. Jika wajib pajak sudah bisa menerima teknologi baru, maka wajib pajak tersebut tidak perlu ragu-ragu untuk melaporkan pajaknya menggunakan sistem $e$-filling.

Berdasarkan Technology Acceptance Model (TAM) terdapat dua faktor yang mempengaruhi integrasi teknologi. Salah satunya yaitu manfaat yang berarti dengan menggunakan sistem dipercaya dapat mendatangkan manfaat bagi orang yang menggunakkannya dan akan meningkatkan kinerjanya (Zaidi et al., 2017).

Hasil penelitian yang dilakukan oleh Desmayanti (2012), Gunawan (2017) mendapatkan hasil kesiapan teknologi informasi berpengaruh positif terhadap minat wajib pajak dalam menggunakan sistem e-filling. Semakin baik tingkat kesiapan teknologi informasi yang diperlukan untuk pemakaian sistem maka semakin tinggi minat wajib pajak melaporkan SPT nya menggunakan sistem $e$ filling. Berdasarkan uraian, maka hipotesis pertama dalam penelitian ini adalah sebagai berikut.

$\mathrm{H}_{1}$ : Kesiapan teknologi informasi berpengaruh positif pada minat wajib pajak dalam menerapkan sistem $e$-filling.

Persepsi kebermanfaatan adalah suatu tingkatan dimana seseorang percaya bahwa suatu penggunaan teknologi tertentu akan meningkatkan prestasi kerja orang tersebut. Persepsi kebermanfaatan mengindikasikan bahwa semakin banyak manfaat yang didapat dari penggunaan $e$-filling maka semakin banyak minat wajib pajak melaporkan SPT nya menggunakan e-filling. Dalam technology acceptance model (TAM) menjelaskan bahwa faktor-faktor yang mempengaruhi 
diterima atau di tolaknya suatu teknologi dalam konteks kegunaan dan kemudahan.

Berdasarkan technology acceptance model (TAM), dapat diartikan bahwa persepsi kebermanfaatan dalam menggunakan e-filling merupakan pandangan subyektif wajib pajak mengenai manfaat yang diperoleh oleh wajib pajak dalam menggunakan e-filling. Sesuai dengan TAM kegunaan juga dipengaruhi oleh kemudahan, karena semakin mudah suatu sistem digunakan maka sistem tersebut dirasakan bermanfaat. Rasa mudah menggunakan sistem teknologi informasi akan menimbulkan perasaan dalam dirinya bahwa sistem itu mempunyai kegunaan.

Penelitian yang dilakukan Desmayanti (2012) dan (Khaddafi et al., 2018) menemukan hasil penelitian ini menunjukkan bahwa persepsi kemudahan dan persepsi kegunaan berpengaruh positif terhadap intensitas perilaku dalam penggunaan $e$-filling, hal ini menunjukkan bahwa adanya pengaruh niat perilaku. Sama halnya dengan penelitian Noviandini (2012), Widia (2018), menemukan bahwa persepsi kebermanfaatan berpengaruh signifikan terhadap penggunaan $e$ filling. Berdasarkan uraian, maka hipotesis kedua dalam penelitian ini adalah sebagai berikut.

$\mathrm{H}_{2}$ : Persepsi kebermanfaatan berpengaruh positif pada minat wajib pajak dalam menerapkan sistem $e$-filling.

Efektivitas sistem adalah gambaran sejauh mana target dicapai dari suatu kumpulan sumber daya yang diatur untuk mengumpulkan, memproses, menyimpan data. Efektivitas sistem dalam pelaporan pajak menggunakan $e$-filling dapat dilihat dari kelebihan-kelebihan yang dihasilkan e-filling, seperti menghemat waktu dan biaya. Task technology fit (TTF) yang dikembangkan oleh Goodhue \& Thompson (1995), menjelaskan bagaimana teknolgi berdampak dalam membantu individu mengerjakan tugas. Secara langsung teori ini berpegang bahwa teknologi memiliki dampak positif terhadap kinerja individu dan dapat digunakan jika kemampuan teknologi tersebut cocok dengan tugas-tugas yang harus dihasilkan oleh pengguna.

Berdasarkan teori task technology fit (TTF), dalam konteks penelitian ini dapat diartikan efektivitas sistem pelaporan pajak dengan menggunakan $e$-filling dapat dilihat dari kelebihan-kelebihan yang dihasilkan melalui e-filling seperti menghemat waktu dan biaya, serta kualitas sistem dan kualita informasi yang dapat memberikan kepuasan kepada wajib pajak.

Penelitian yang dilakukan oleh Sugiharti (2015) menemukan hasil bahwa efektivitas sistem dan kelayakan sistem berpengaruh signifikan terhadap kepuasan wajib pajak orang pribadi. Penelitian yang dilakukan oleh Anggraini (2017) mengungkapkan bahwa efektivitas sistem berpengaruh positif terhadap kepuasan wajib pajak orang pribadi. Berdasarkan uraian, maka hipotesis ketiga dalam penelitian ini adalah sebagai berikut.

$\mathrm{H}_{3}$ : Pengaruh efektivitas sistem berpengaruh positif pada minat wajib pajak dalam menggunakan $e$-filling.

Kelayakan sistem adalah ukuran seberapa menguntungkan atau seberapa praktis pengembangan sistem informasi terhadap kepuasan dan kenyamanan pengguna. Teori Task Technology Fit (TTF) yang dikembangkan yang oleh Goodhue \& Thompson (1995), berpegang bahwa teknologi memiliki dampak 
positif terhadap kinerja individu dan dapat digunakan jika kemampuan teknologi tersebut cocok dengan tugas-tugas yang harus dihasilkan oleh pengguna.

Berdasarkan teori Task Technology Fit (TTF), dalam konteks penelitian ini dapat diartikan bahwa suatu sistem dapat dikatakan memiliki kelayakan apabila memiliki kecocokan hasil dengan yang diharapkan pengguna, dan pengguna merasa puas dan rasa ingin menggunakan e-filling tersebut meningkat.

Penelitian yang dilakukan oleh Sugiharti (2015), Anggraini (2017) menemukan hasil bahwa kelayakan sistem berpengaruh signifikan terhadap kepuasan wajib pajak orang pribadi. Berdasarkan uraian, maka hipotesis keempat dalam penelitian ini adalah sebagai berikut.

$\mathrm{H}_{4}$ : Kelayakan sistem berpengaruh positif pada minat wajib pajak dalam menerapkan sistem $e$-filling.

\section{METODE PENELITIAN}

Penelitian ini menggunakan metode pendekatan kuantitatif yang berbentuk asosiatif, karena menjelaskan hubungan antara variabel satu dengan variabel lainnya (Sugiyono, 2017:16) yang dilakukan di KPP Pratama Badung Selatan berlokasi di Jalan Tantular No. 4, Dangin Puri Kelod, Kota Denpasar, Bali. Variabel penelitian diukur menggunakan skala likert lima (5) poin yang terdiri dari (1) sangat tidak setuju, (2) tidak setuju, (3) netral, (4) setuju, dan (5) sangat setuju.

Kesiapan teknologi informasi didefinisikan sebagai ukuran individu yang siap untuk menerima perkembangan teknologi termasuk dengan munculnya sistem e-filling. Indikator dari variabel kesiapan teknologi infomasi menurut Mujiyati (2013:421) adalah 1) tersedianya koneksi internet yang baik, 2) tersedianya sarana dan fasilitas software dan hardware yang baik, 3) SDM yang paham akan teknologi.

Persepsi kebermanfaatan merupakan suatu pemikiran mengenai penggunaan teknologi informasi dapat meningkatkan kinerja dan memberikan keuntungan bagi penggunanya. Indikator dari variabel persepsi kebermanfaatan menurut Jogiyanto (2008:115) adalah pekerjaan lebih mudah, meningkatkan kinerja individu, meningkatkan efektivitas kerja, meningkatkan produktivitas, pekerjaan lebih cepat selesai, mampu memberikan manfaat bagi individu.

Efektivitas sistem adalah suatu ukuran yang mengungkapkan seberapa jauh (kuantitas, kualitas, dan waktu) telah mampu dicapai. Indikator dari variabel efektivitas sistem menurut (Bodnar \& Hopwood (2000) dalam Anggraini (2017:30) adalah keamanan data, waktu (kecepatan dan ketepatan), ketelitian, relevansi.

Kelayakan sistem adalah ukuran akan seberapa menguntungkan atau seberapa praktis pengembangan sistem informasi terhadap pengguna. Indikator dari variabel kelayakan sistem menurut O'Brien (2005) adalah Kelayakan organisasi, Kelayakan ekonomi, Kelayakan teknis, Kelayakan operasional.

Minat dalam menggunakan sistem e-filling adalah keadaan dimana seseorang mempunyai perhatian terhadap sesuatu hal dan mempunyai keinginan untuk menggunakannya lebih lanjut lagi. Indikator dalam variabel minat wajib pajak dalam menggunakan sistem e-filling menurut Ekamaulana (2016) adalah keinginan untuk menggunakan, selalu mencoba menggunakan berlanjut di masa yang akan datang. 
Populasi merupakan wilayah generalisasi yang terdiri atas obyek/subyek yang mempunyai kualitas dan karakteristik tertentu yang ditetapkan oleh peneliti untuk dipelajari dan kemudian ditarik kesimpulannya (Sugiyono, 2017:80). Populasi dalam penelitian ini adalah wajib pajak orang pribadi yang terdaftar di KPP Pratama Badung Selatan.

Sampel dalam penelitian ini sebanyak 100 responden. Metode pengambilan sampel dalam penelitian ini menggunakan metode purposive sampling yaitu dengan menentukan indikator-indikator spesifik sehubungan data yang diperlukan, yang dimiliki oleh populasi yang telah ditentukan sebelumnya. Kriteria sampel yang digunakan adalah 1) Wajib pajak terdaftar di KPP Pratama Badung Selatan 2) Wajib Pajak Orang Pribadi yang melaporkan SPT nya menggunakan sistem $e$-filling.

Kuesioner tersebut disebarkan dalam bentuk google form secara langsung kepada wajib pajak orang pribadi karena wajib pajak melaporkan pajaknya secara online. Dalam penelitian ini digunakan teknik analisis regresi linier berganda yang diuji dengan tingkat signifikansi 0,05 . Untuk dapat melakukan analisis regresi berganda perlu pengujian asumsi klasik sebagai persyaratan dalam analisis agar datanya dapat bermakna dan bermanfaat. Adapun uji asumsi klasik yang dipakai adalah uji normalitas, uji multikolinearitas, uji heteroskesastiditas. Adapun persamaan regresi linier berganda menurut (Sugiyono, 2017:275) dapat dirumuskan sebagai berikut.

$$
Y=\alpha+\beta_{1} X_{1}+\beta_{2} X_{2}+\beta_{3} X_{3}+\beta_{4} X_{4}+\varepsilon
$$

Keterangan:

$$
\begin{array}{ll}
\mathrm{Y} & =\text { Minat wajib pajak menggunakan } e \text {-filling } \\
\mathrm{a} & =\text { Konstanta } \\
\beta_{1}-\beta_{4} & =\text { Koefisien regresi } \\
\mathrm{X}_{1} & =\text { Kesiapan teknologi informasi } \\
\mathrm{X}_{2} & =\text { Persepsi Kebermanfaatan } \\
\mathrm{X}_{3} & =\text { Efektivitas Sistem } \\
\mathrm{X}_{4} & =\text { Kelayakan Sistem } \\
\varepsilon & =\text { standar eror }
\end{array}
$$

\section{HASIL DAN PEMBAHASAN}

Jumlah kuesioner yang disebarkan kepada responden adalah sebanyak 100 kuesioner dan seluruhnya telah dikembalikan. Dari kuesioner yang dikembalikan tersebut tidak ada yang gugur, sehingga dapat digunakan seluruhnya. Karakteristik responden dikelompokkan menurut jenis kelamin, umur, tingkat pendidikan, jenis pekerjaan, pernah menggunakan sistem e-filling, dan pengalaman menggunakan sistem $e$-filling.

Data karakteristik responden berdasarkan jenis kelamin menunjukkan bahwa 32 responden (32 persen) responden berjenis kelamin laki-laki dan sisanya sebesar (68 persen) responden berjenis perempuan. Data karakkteristik responden berdasarkan usia menunjukkan bahwa responden yang berusia kurang dari 25 tahun berjumlah 28 responden (28 persen), usia 25-30 tahun berjumlah 31 responden (31 persen), usia 31-35 tahun berjumlah 23 responden ( 23 persen), usia 36-40 tahun berjumlah 8 responden (8 persen), dan usia lebih dari 45 tahun berjumlah 6 responden (6 persen). Hal ini membuktikan bahwa wajib pajak orang 
pribadi yang menerapkan sistem e-filling didominasi oleh responden yang berusia 25-30 tahun. Data karakkteristik responden berdasarkan tingkat pendidikan terakhir pada menunjukkan bahwa responden dengan pendidikan terakhir SMA/SMK berjumlah 10 responden (10 persen), Diploma berjumlah 15 responden (15 persen), Sarjana berjumlah 55 responden (55 persen), Magister berjumlah 15 orang (15 persen), dan Doktor berjumlah 5 responden ( 5 persen). Hal ini membuktikan bahwa wajib pajak orang pribadi yang menerapkan sistem e-filling didominasi oleh wajib pajak yang menempuh pendidikan terakhir Sarjana. Data karakkteristik responden berdasarkan usia menunjukkan bahwa responden yang bekerja swasta berjumlah 55 responden ( 55 persen), PNS berjumlah 9 responden (9 persen), wiraswasta berjumlah 17 responden (17 persen), dan sisanya sebanyak 19 responden (19 persen) responden bekerja lainnya. Hal ini membuktikan bahwa wajib pajak orang pribadi yang menerapkan sistem e-filling didominasi oleh wajib pajak yang bekerja swasta. Data karakkteristik responden berdasarkan usia menunjukkan bahwa responden yang sudah menggunakan sistem e-filling sebanyak 100 responden (100 persen). Data karakkteristik responden berdasarkan usia menunjukkan bahwa responden yang sudah menggunakan sistem $e$-filling kurang dari 1 tahun beberjumlah 14 responden (14 persen), 1-2 tahun berjumlah 47 responden (47 persen), 3-4 tahun berjumlah 34 responden (34 persen), dan responden yang sudah menggunakan sistem $e$-filling lebih dari 5 tahun berjumlah 5 reponden (5 persen). Hal ini membuktikan bahwa pengalaman wajib pajak orang pribadi yang sudah menerapkan sistem $e$-filling berjumlah 1-2 tahun.

Suatu kuesioner dinyatakan valid apabila pernyataan dalam kuesioner mampu mengungkapkan sesuatu yang akan diukur oleh kuesioner tersebut. Pengujian validitas dapat dilakukan dengan menghitung korelasi antara skor faktor atas masing-masing butir pernyataan kuesioner dengan skor total sehingga didapat nilai pearson correlation. Untuk memenuhi syarat validitas, maka butir pernyataan dalam penelitian harus memiliki nilai koefisien korelasi $>0,3$. Pengujian instrument ini, peneliti menggunakan 30 kuesioner yang disebarkan kepada responden sebenarnya. Uji validitas ini diukur dengan bantuan perangkat lunak SPSS 24 for windows.

Hasil uji validitas menunjukkan bahwa butir-butir pernyataan dalam kuesioner yang merupakan instrument penelitian yang digunakan untuk mengukur variabel kesiapan teknologi informasi, persepsi kebermanfaatan, efektivitas sistem, dan kelayakan sistem dan minat wajib pajak dalam menerapkan sistem e-filling memiliki nilai koefisien korelasi terhadap skor total seluruh pernyataan lebih besar dari 0,30 . Hal ini berarti seluruh butir pernyataan dalam instrument penelitian tersebut valid sehingga layak digunakan sebagai instrument penelitian.

Uji reliabilitas menunjukkan sejauh mana suatu pengukuran dapat memberikan hasil konsisten jika dilakukan pengukuran kembali terhadap gejala yang sama dengan alat ukur yang sama. Kuesioner dapat dikatakan reliabel atau andal apabila jawaban seseorang terhadap pertanyaan atau pernyataan bersifat stabil atau konsisten dari waktu ke waktu. Uji reliabilitas pada penelitian ini menggunakan uji statistik Cronbach's Alpha. Suatu instrument dikatakan reliabel apabila nilai Cronbach's Alpha lebih dari 0,6. Hasil uji reliabilitas menunjukkan bahwa seluruh instrument penelitian memiliki nilai Cronbach's Alpha lebih dari 0,6. 
Hal ini berarti seluruh variabel telah memenuhi syarat keandalan atau reliabilitas sehingga layak digunakan untuk melakukan penelitian.

Hasil uji normalitas menunjukkan nilai signifikansi sebesar 0,833 yang lebih besar dari 0,05. Oleh karena nilai signifikansi uji Kolmogorov-Smirnov lebih dari 0,05 maka dapat disimpulkan bahwa data yang diuji berdistribusi normal.

Tabel 1. Hasil Uji Multikolinearitas

\begin{tabular}{lcc}
\hline Variabel & \multicolumn{2}{c}{ Collinearity Statistic } \\
\cline { 2 - 3 } & Tolerance & VIF \\
\hline Kesiapan Teknologi Informasi $\left(\mathrm{X}_{1}\right)$ & 0,653 & 1,531 \\
Persepsi Kebermanfaatan $\left(\mathrm{X}_{2}\right)$ & 0,401 & 2,493 \\
Efektivitas Sistem $\left(\mathrm{X}_{3}\right)$ & 0,348 & 2,875 \\
Kelayakan Sistem $\left(\mathrm{X}_{4}\right)$ & 0,360 & 2,780 \\
\hline
\end{tabular}

Sumber: Data Penelitian, 2021

Hasil uji multikolinearitas menunjukkan bahwa variabel kesiapan teknologi informasi memiliki nilai tolerance $0,653>0,10$ dan nilai VIF 1,531 $<10$. Variabel persepsi kebermanfaatan memiliki nilai tolerance 0,401 >0,1 dan nilai VIF 2,493< 10. Variabel efektivitas sistem memiliki nilai tolerance $0,348>0,1$ dan nilai VIF 2,875 $<10$. Variabel kelayakan sistem memiliki nilai tolerance $0,360>0,1$ dan nilai VIF $2,780<10$. Hal ini dapat disimpulkan tidak terjadi multikolinearitas diantara keempat variabel bebas dalam penelitian ini.

Hasil uji heteroskedastisitas menunjukkan bahwa variabel kesiapan teknologi informasi memiliki nilai Sig. 0,145, variabel persepsi kebermanfaatan memiliki nilai Sig. 0,217, variabel efektivitas sistem memiliki nilai Sig. 0,103, variabel kelayakan sistem memiliki nilai Sig. 0,950. Apabila dibandingkan, nilai signifikansi masing-masing variabel bebas seluruhnya lebih besar dari 0,05. Hal ini berarti bahwa pada seluruh variabel bebas yang terdapat dalam model regresi, tidak mengandung gejala heteroskedastisitas.

Analisis regresi linier berganda merupakan teknik analisis data yang digunakan untuk mengetahui hubungan secara linier antara variabel independen dengan variabel dependen, yakni pengaruh kesiapan teknologi informasi $\left(X_{1}\right)$, persepsi kebermanfaatan $\left(X_{2}\right)$, efektivitas sistem $\left(X_{3}\right)$, kelayakan sistem $\left(X_{4}\right)$ terhadap minat wajib pajak dalam menerapkan sistem e-filling $(\mathrm{Y})$. Hasil analisis regresi linier berganda pada penelitian ini disajikan dalam Tabel 2.

Tabel 2. Hasil Analisis Regresi Linier Berganda

\begin{tabular}{llllll}
\hline Model & $\begin{array}{l}\text { Unstandarddized } \\
\text { Beta }\end{array}$ & $\begin{array}{l}\text { Std. } \\
\text { Error }\end{array}$ & $\begin{array}{l}\text { Standardize } \\
\text { Beta }\end{array}$ & $\mathrm{t}$ & Sig. \\
\hline (Constant) & 1,340 & 0,316 & & 4,235 & 0,000 \\
Kesiapan Teknologi Informasi & 0,526 & 0,083 & 0,561 & 6,326 & 0,000 \\
Persepsi Kebermanfaatan & $-0,027$ & 0,073 & $-0,042$ & $-0,371$ & 0,711 \\
Efektivitas Sistem & $-0,069$ & 0,083 & -100 & $-0,825$ & 0,411 \\
Kelayakan Sistem & 0,248 & 0,090 & 0,332 & 2,775 & 0,007 \\
R Square & $: 0,512$ & & & & \\
Adjusted R Square & $: 0,492$ & & & & \\
F Statistik & $: 24,936$ & & & & \\
Signifikansi & $: 0,000$ & & & &
\end{tabular}

Sumber: Data Penelitian, 2021

Hipotesis $1\left(\mathrm{H}_{1}\right)$ yang diajukan menyatakan kesiapan teknologi informasi berpengaruh positif pada minat wajib pajak dalam menerapkan sistem e-filling. 
Hasil analisis menunjukkan bahwa variabel kesiapan teknologi informasi memiliki pengaruh positif pada minat wajib pajak dalam menerapkan sistem $e$ filling. Hal ini menandakan hipotesis $1\left(\mathrm{H}_{1}\right)$ dalam penelitian ini diterima. Hasil penelitian memberikan makna bahwa semakin tinggi tingkat kesiapan teknologi yang dimiliki, maka semakin tinggi pula minat untuk menerapkan sistem $e$-filling tersebut.

Hasil penelitian ini sejalan dengan Technology of acceptance model (TAM). Technology of acceptance model (TAM) menjelaskan adanya reaksi dan persepsi pengguna teknologi informasi yang akan mempengaruhi sikap wajib pajak dalam penerimaan teknologi tersebut. Tingkat kesiapan teknologi mempengaruhi keinginan dalam menggunakan sistem informasi. Minat akan timbul dalam menggunakan sejalan dengan pribadi individu yang bersedia menerima akan adanya kemajuan teknologi baru yang mempermudah pelaporan pajaknya. Oleh karena itu, dapat dikatakan bahwa tingginya tingkat kesiapan teknologi infromasi maka semakin tinggi pula minat penggunaan sistem online.

Kesiapan teknologi pada dasarnya dipengaruhi oleh individu itu sendiri, apakah dari dalam diri individu siap menerima yang namanya perkembangan teknologi khususnya dalam hal ini adalah e-filling. Selain dari individu kesiapan suatu teknologi dapat di lihat dari teknologi seperti adanya software dan hardware yang memadai.

Hasil penelitian sejalan dengan penelitian Desmayanti (2012), Maryani (2019). Penelitian Mujiyani \& Wahyuningtyas (2019) dan Wibisono \& Toly (2014) juga menemukan bahwa kesiapan teknologi informasi berpengaruh terhadap penggunaan sistem $e$-filling.

Hipotesis $2\left(\mathrm{H}_{2}\right)$ yang diajukan menyatakan persepsi kebermanfaatan berpengaruh positif pada minat wajib pajak dalam menerapkan sistem e-filling. Berdasarkan hasil analisis penelitian ditemukan bahwa persepsi kebermanfaatan tidak berpengaruh pada minat wajib pajak dalam menerapkan sistem e-filling. Hal ini menandakan hipotesis $2\left(\mathrm{H}_{2}\right)$ dalam penelitian ini ditolak. Hasil penelitian memberikan makna bahwa baik atau tidaknya persepsi kebermanfaatan yang diberikan oleh wajib pajak, tidak memengaruhi minatnya untuk menerapkan sistem $e$-filling.

Hasil penelitian ini belum berhasil membuktikan bahwa persepsi kebermanfaatan sebagai bukti empiris yang mendukung Technology Acceptance Model (TAM). Technology Acceptance Model (TAM) menyatakan bahwa adanya persepsi kebermanfaatan merupakan variabel internal dari setiap orang dalam menggunakan teknologi. Banyak manfaat diperoleh saat menggunakan sistem $e$ filling salah satunya untuk membantu wajib pajak dalam pelaporan SPT. Namun tidak semua individu menganggap sistem $e$-filling berguna untuk mereka, karena selama wajib pajak menggunakan sistem e-filling belum merasa bahwa menggunakan sistem e-filling dalam melaporkan SPT dapat memberikan manfaat.

Hasil penelitian ini mendukung penelitian terdahulu yang dilakukan Sesa (2014) yang menyatakan bahwa persepsi kebermanfaatan tidak mempengaruhi wajib pajak dalam menggunakan sistem $e$-filling dalam melaporkan SPT Tahunan. Namun hasil penelitian ini bertentangan dengan hasil penelitian yang dilakukan oleh Noviandini (2012), yang menyatakan bahwa persepsi kebermanfaatan berpengaruh terhadap penggunaan fasilitas sistem $e$-filling. 
Hipotesis $3\left(\mathrm{H}_{3}\right)$ yang diajukan menyatakan efektivitas sistem berpengaruh positif pada minat wajib pajak dalam menerapkan sistem e-filling. Berdasarkan hasil analisis penelitian ditemukan bahwa efektivitas sistem tidak berpengaruh pada minat wajib pajak dalam menerapkan sistem $e$-filling. Hal ini menandakan hipotesis $3\left(\mathrm{H}_{3}\right)$ dalam penelitian ini ditolak. Hasil penelitian memberikan makna bahwa baik atau tidaknya efektivitas yang dihasilkan oleh sistem saat wajib pajak menerapkan sistem e-filling tidak memengaruhi minatnya untuk menerapkan sistem $e$-filling.

Hasil penelitian ini belum berhasil membuktikan bahwa efektivitas sistem sebagai bukti empiris yang mendukung Task Technology Fit (TTF). Task Technology Fit (TTF) menjelaskan bahwa teknologi informasi hanya akan digunakan jika fungsi dan manfaat tersedia untuk mendukung aktivitas pengguna, dalam hal ini sistem e-filling. Hal ini terjadi karena wajib pajak mengalami keraguan dan menganggap jika wajib pajak menggunakan sistem e-filling akan menimbulkan risiko saat menggunakannya dan adanya kendala yang sering wajib pajak hadapi seperti kondisi internet yang tidak stabil mengakibatkan sistem eror pada saat menggunakan sistem, dan kurangnya pengetahuan dan pemahaman cara mengoperasikan sistem.

Hasil penelitian ini mendukung penelitian terdahulu yang dilakukan oleh Aziz \& Adestya (2020) menyatakan bahwa efektivitas layanan e-filling terhadap wajib pajak tidak mempengaruhi wajib pajak dalam menggunakan sistem $e$-filling dalam melaporkan SPT Tahunan. Namun hasil penelitian ini bertentangan dengan hasil penelitian yang dilakukan oleh Sugiharti (2015), Anggraini (2017) dan Ario (2017) yang menyatakan bahwa efektivitas sistem berpengaruh terhadap kepuasan wajib pajak.

Hipotesis $4\left(\mathrm{H}_{4}\right)$ menyatakan bahwa kelayakan sistem berpengaruh positif pada minat wajib pajak dalam menerapkan sistem e-filling. Hasil analisis menunjukkan bahwa variabel kelayakan sistem memiliki pengaruh positif pada minat wajib pajak dalam menerapkan sistem e-filling. Hal ini menandakan hipotesis $4\left(\mathrm{H}_{4}\right)$ dalam penelitian ini diterima. Hasil penelitian memberikan makna bahwa semakin tinggi tingkat kelayakan yang dimiliki suatau sistem, maka semakin tinggi pula minat untuk menerapkan sistem $e$-filling tersebut.

Hasil penelitian ini sejalan dengan teori Task Technology Fit (TTF). Task Technology Fit (TTF) menjelaskan bahwa teknologi informasi hanya akan digunakan jika fungsi dan manfaat tersedia untuk mendukung aktivitas pengguna, dalam hal ini sistem $e$-filling. Adanya fasilitas sistem yang baru yaitu sistem $e$-filling, masyarakat terbantu akan keberadaan dari sistem tersebut, karena sistem $e$-filling dapat memangkas biaya karena pelaporan menggunakan sistem $e$ filling tidak dikenakan biaya dan dapat menghemat waktu yang dibutuhkan oleh wajib pajak dalam melaporkan SPT nya ke kantor pelayanan pajak, hal tersebut menunjukkan bahwa sistem e-filling layak digunakan sebagai sarana pelaporan pajak.

Hasil penelitian sejalan dengan penelitian Sugiharti (2015), Anggraini (2017) yang menyatakan bahwa kelayakan sistem berpengaruhkepuasan wajib pajak, semakin tinggi tingkat keuntungan yang diberikan saat menggunakan sistem, maka wajib pajak akan semakin sering pula menggunakan sistem $e$-filling. 


\section{SIMPULAN}

Berdasarkan hasil analisis dan pembahasan pada yang telah diuraikan, maka ditarik kesimpulan sebagai berikut: 1) Kesiapan teknologi informasi berpengaruh positif pada minat wajib pajak dalam menerapkan sistem e-filling. 2) Persepsi kebermanfaatan tidak berpengaruh pada minat wajib pajak dalam menerapkan sistem e-filling. 3) Efektivitas sistem tidak berpengaruh pada minat wajib pajak dalam menerapkan sistem e-filling. 4) Kelayakan sistem berpengaruh positif pada minat wajib pajak dalam menerapkan sistem e-filling.

Kepada peneliti selanjutnya dapat menambahkan variabel lain yang berhubungan dengan minat menerapkan sistem e-filling, sehingga dapat memberikan gambaran lebih luas mengenai faktor-faktor yang mempengaruhi minat dalam menerapkan sistem $e$-filling. Diharapkan DJP meningkatkan kinerja sistem agar dapat mengurangi sistem mengalami eror ketika wajib pajak sedang mengaksesnya dan melakukan sosialisasi mengenai cara penggunaan, manfaat, dan kemudahan saat menggunakan sistem $e$-filling.

\section{REFERENSI}

Adnyana, I. M. D., \& Yuesti, A. (2020). The Effect of Applying e-SPT, e-invoicing, and e-Filing Against Taxpayer Compliance at the East Denpasar Pratama Tax Service Office. Journal of Management Info, 7(3), 156-167. https://doi.org/10.31580/jmi.v7i3.1548

Aliah, N. (2020). The Role of E-Filing Improving Taxpayer Compliance in Indonesia. Accounting and Business Journal, 2(1), 1-9.

Anggraini, D. (2017). Analisis pemahaman teknologi informasi, efektivitas, dan kelayakan e-filing terhadap tingkat kepuasan wajib pajak di Kantor Pelayanan Pajak Pratama Surabaya Gubeng. Widya Mandala Catholic University Surabaya.

Ario, S. (2017). Analisis Fasilitas Sistem E-Filling Dalam Efektivitas Pelaporan SPT Tahunan Di Kota Pekanbaru (Studi Pada KPP Pratama Pekanbaru Tampan).

Ariyanto, D., Dewi, A. A., \& Jhuniantara, I. M. G. (2020). Perceived learning assistance and perceived community building assistance: Study on e-learning system. Systematic Reviews in Pharmacy, 11(12), 330-339. https:// doi.org/10.31838/srp.2020.12.53

Ariyanto, D., Subroto, B., Purnomosidhi, B., \& Rosidi. (2014). Does the Balinese Tri Hita Karana Culture Affect the Adoption and Usage of Information Technology Systems? Information and Knowledge Management.

Aziz, A., \& Adestya, G. I. (2020). Efektivitas Layanan E-Filling Terhadap Wajib Pajak Orang Pribadi di Kantor Pelayanan Pajak Pratama Malang Selatan. Jurnal Akuntansi Perpajakan, 6(1).

Bawazier, F. (2011). Reformasi Pajak di Indonesia. Jurnal Legislasi Indonesia, 8(1), 112.

Damayanti, F., \& Fauzi, A. (2016). Pengaruh Fasilitas Drop Box, E-Spt Dan E-Filing Dalam Penyampaian Surat Pemberitahuan (Spt) Terhadap Kepuasan Wajib Pajak. Akuntabilitas, 8(3), 225-237. https:/ / doi.org/10.15408/akt.v8i3.2774

Davis, F. D., Bagozzi, R. P., \& Warshaw, P. R. (1989). User Acceptance of Computer Technology: A Comparison of Two Theoretical Models. Management Science. https://doi.org/10.1287/mnsc.35.8.982

Davis, F. D., \& Venkatesh, V. (1996). A critical assessment of potential 
measurement biases in the technology acceptance model: Three experiments. International Journal of Human Computer Studies. https://doi.org/10.1006/ijhc.1996.0040

Desmayanti, E. (2012). Faktor-Faktor Yang Mempengaruhi Penggunaan Fasilitas E-Filling Oleh Wajib Pajak Sebagai Sarana Penyampaian Spt Masa Secara Online Dan Realtime. Jurnal Akuntansi, 1(1), 1-12.

Devina, S., \& Waluyo. (2016). Pengaruh Persepsi Kegunaan, Persepsi Kemudahan, Kecepatan, Keamanan 75 dan Kerahasiaan Serta Kesiapan Teknologi Informasi Wajib Pajak terhadap Penggunaan e-Filing Bagi Wajib Pajak Orang Pribadi Di Kota Tangerang, Kecamatan Karawaci. Jurnal ULTIMA Accounting, 8(1), 75-91. https://doi.org/10.31937/akuntansi.v8i1.578

Gefen, D., \& Straub, D. (2000). The Relative Importance of Perceived Ease of Use in IS Adoption: A Study of E-Commerce Adoption. Journal of the Association for Information Systems. https:/ / doi.org/10.17705/1jais.00008

Goodhue, D. L., \& Thompson, R. L. (1995). Task-technology fit and individual performance. MIS Quarterly: Management Information Systems. https:// doi.org/10.2307/249689

Gunawan, T., Suprapti, E., \& Kurniawati, E. T. (2017). Persepsi Wajib Pajak Mengenai E-Filing dan Pengaruhnya terhadap Tingkat Kepatuhan Wajib Pajak Orang Pribadi Dalam Melaporkan Pajak. Jurnal Reviu Akuntansi Dan Keuangan, 4(2).

Islam, N. (2011). The Determinants of the Post-Adoption Satisfaction of Educators with an E-Learning System. Journal of Information Systems Education, 22(4), 319-331.

Khaddafi, M., Aspan, H., Heikal, M., Wahyuddin, Falahuddin, \& Humaira, Z. (2018). Effect of perception of facilities, intensity of conduct, and satisfaction of tax payers to submission of letter by E-filing notice on tax service. Emerald Reach Proceedings Series, 1, 583-587. https://doi.org/10.1108/978-1-78756793-1-00001

Lim, W. M., \& Ting, D. H. (2012). E-shopping: An analysis of the technology acceptance model. Modern Applied Science. https://doi.org/10.5539/mas.v6n4p49

Martini, I. A. O. M., \& Adriati, I. G. A. W. (2020). Important Indicators Affecting Interest of Taxpayer Behavior. Jurnal Riset Akuntansi, 10(2), 132-140. https://doi.org/https://doi.org/10.36733/juara.v10i2.1339

Maryani, N. K. J. (2019). Pengaruh Perilaku Wajib Pajak Terhadap Kepatuhan Wajib Pajak Dengan Penggunaan E-Filing Sebagai Variabel Intervening Pada KPP Pratama Gianyar. JSAM (Jurnal Sains, Akuntansi Dan Manajemen), 1(2), 107-150.

Ming Ling, L., \& Muhammad, I. (2006). Taxation and Technology: Technology Readiness of Malaysian Tax Officers in Petaling Jaya Branch. Journal of Financial Reporting and Accounting, 4(1), 147-163. https://doi.org/10.1108/19852510680001587

Mujiyati, \& Wahyuningtyas. (2019). Analisis Faktor-faktor yang memengaruhi Penggunaan E-filing Bagi Wajib Pajak Orang Pribadi (Studi Empiris Pada Wajib Pajak di KPP Surakarta). Proceeding of The Urecol, 169-179.

Mustapha, B., \& Obid, S. N. B. S. (2015). Tax Service Quality: The Mediating Effect 
of Perceived Ease of Use of the Online Tax System. Procedia - Social and Behavioral Sciences, 172, 2-9. https://doi.org/10.1016/j.sbspro.2015.01.328

Noviandini, N. C. (2012). Pengaruh Persepsi Kebermanfaatan, Persepsi Kemudahan Penggunaan, Dan Kepuasan Wajib Pajak Terhadap Penggunaan E-Filling Bagi Wajib Pajak Di Yogyakarta. Jurnal Nominal, 1(1), 15-22. https://doi.org/10.32639/jimmba.v2i4.644

Nur, T. F., \& Valentinus, F. (2020). Kelemahan Penggunaan E-Filling Pada Pengisian Surat Pemberitahuan Tahunan Pajak Penghasilan Orang Pribadi Dengan Periode Penghasilan Kurang Dari 12 Bulan. Jurnal Administrasi Bisnis Terapan, 2(2), 92-102. https:// doi.org/10.7454/jabt.v2i2.95

Nurhayati, Anam, H., \& Manalu, R. V. B. (2020). Kegunaan, Persepsi Kemudahan, Persepsi Kerahasiaan, D A N Informasi, Kesiapan Teknologi Terhadap Intensitas Perilaku Dalam Penggunaan E-Filing. Jurnal Geo Ekonomi, 11(1), 115. https://doi.org/https://doi.org/10.36277/geoekonomi.v11i1.104

Nurjannah, N., Rasuli, M., \& Rusli, R. (2017). Pengaruh Persepsi Kebermanfaatan, Persepsi Kemudahan, Kepuasan, Kecepatan, Keamanan Dan Kerahasiaan Terhadap Penggunaan Fasilitas E-filing Sebagai Sarana Penyampaian Spt Masasecara Online Dan Realtime Bagi Wajib Pajak Badan Di Dumai. Jurnal Online Mahasiswa Fakultas Ekonomi Universitas Riau, 4(1), 1828-1842.

Paramaduhita, A. V., \& Mustikasari, E. (2018). Non-employee individual taxpayer compliance. Asian Journal of Accounting Research, 3(1), 112-122. https://doi.org/10.1108/ajar-06-2018-0007

Perkasa, A. T. (2016). Pengaruh Persepsi Kebermanfaatan, Persepsi Kemudahan Penggunaan dan Persepsi Kepercayaan Wajib Pajak Terhadap Minat Menggunakan E-filing Sebagai Sarana Pelaporan Pajak (Study Kasus di PT Pelabuhan Indonesia III Cabang Benoa). Jurnal Ilmiah Mahasiswa FEB, 4(2).

Prawati, L. D., \& Britania, H. (2020). The Impact Of Information Technology On Taxation: Corporate Taxpayers' Interest In Using Djp Online System. PalArch's Journal of Archaeology of Egypt/Egyptology, 17(7), 2451-2462.

Rakhmawati, H., T, S., \& Rusydi, M. K. (2020). Influence of TAM and UTAUT Models Of The Use Of E-Filling On Tax Compliance. International Journal of Research in Business and Social Science, 9(1), 106-111. https://doi.org/10.20525/ijrbs.v9i1.576

Sesa, E. S. (2014). Pengaruh Persepsi Wajib Pajak Orang Pribadi Pada Penerapan EFilling Terhadap Kepatuhan Dalam Menyampaikan SPT Tahunan di Kota Surabaya.

Siregar, K. R. (2011). Kajian mengenai penerimaan teknologi dan informasi menggunakan technology accaptance model (TAM). Rekayasa, 4(1), 27-32.

Sugiharti, M. A., Suhadak, \& Dewantara, R. Y. (2015). Analisis Efektivitas Dan Kelayakan Sistem Pelaporan Pajak Menggunakan E-Filling Terhadap Kepuasan Wajib Pajak. Jurnal Perpajakan (JEJAK), 6(2), 2015.

Sugiyono. (2019). Metode Penelitian Kuantitatif, Kualitatif, dan RED. Alfabeta.

Tahar, A., Riyadh, H. A., Sofyani, H., \& Purnomo, W. E. (2020). Perceived Ease of Use, Perceived Usefulness, Perceived Security and Intention to Use E-Filling: The Role of Technology Readiness. Journal of Asian Finance, Economics and Business, $7(9)$, 537-547. https:// doi.org/10.13106/JAFEB.2020.VOL7.NO9.537

Tam, C., \& Oliveira, T. (2016). Performance impact of mobile banking: using the 
task-technology fit (TTF) approach. International Journal of Bank Marketing, 34(4), 434-457. https:/ / doi.org/10.1108/IJBM-11-2014-0169

Venkatesh, V., \& Davis, F. D. (2000). A Theoretical Extension of the Technology Acceptance Model: Four Longitudinal Field Studies. Management Science, $46(2)$, 186-204.

https://doi.org/http://dx.doi.org/10.1287/mnsc.46.2.186.11926

Wibisono, L. T., \& Toly, A. A. (2014). Analisis faktor-faktor yang mempengaruhi minat wajib pajak dalam penggunaan e-filing di Surabaya. Tax $\mathcal{E}$ Accounting Review, 4(1), 246.

Widia, W. (2018). Pengaruh Persepsi Kebermanfaatan, Kemudahan Dan Resiko Terhadap Keputusan E-Banking Dengan Kepercayaan Sebagai Variabel Intervening (Studi Kasus Mahasiswa IAIN Salatiga). IAIN SALATIGA.

Zaidi, S. K. R., Henderson, C. D., \& Gupta, G. (2017). The moderating effect of culture on e-filing taxes: evidence from India. Journal of Accounting in Emerging Economies, 7(1), 134-152. https://doi.org/10.1108/JAEE-05-20150038 